\title{
Note on Recent Developments
}

\section{Friends of Nature and Public Interest Environmental Litigation}

\author{
Yina LIU \\ Environmental Public Interest Lawyer, Friends of Nature, Beijing \\ liuyina@fonchina.org
}

\section{$1 \quad$ Introduction}

This note looks at the work of the national non-governmental environmental protection organization Friends of Nature (FON). It first explains the organization's environmental law and policy activities and then focuses on a current water pollution case as an example of the kinds of legal work in which it engages. It concludes by addressing the issues that are still prevalent around standing to sue by public interest environmental organizations.

FON was founded in 1994 and is the earliest national non-governmental environmental protection organization in China. Its activities include public environmental protection activities, environmental education, law reform and public interest litigation. The strategic goals of FON include nurturing, and supporting 'green-minded' citizens and promoting more self-organized environmental activities. The public environmental protection activity programs including zero-waste events, 'Blue Sky Lab', 'Low-Carbon Family' and river protection. 'Blue Sky Lab' was initiated by FON as an innovative platform for free public participation in detecting air pollution and developing haze solutions, involving scientists and other professionals, volunteers and members of the general community. This program has conducted various activities, such as 
public lectures on air quality and health, and 'do-it-yourself' (DIY) air purifiers. ${ }^{1}$ 'Low-carbon Family' is a low-carbon household model developed by Friends of Nature that aims to promote energy efficiency solutions to communities, enterprises and schools and to develop energy conservation projects by advocating the concept of 'low- carbon lifestyle' to encourage more people to follow environmentally-friendly lifestyles. It also includes environmental education for children, for them to experience nature, to learn more about and to love nature. FON can attest that there are more and more green citizens emerging in China. With more widespread attention and effort put into environmental issues, FON aims at regaining clear waters and blue skies.

In addition to the programs directed at the general public, FON carries out high-level professional legal work to defend the rights of nature, and to reduce the negative impact of environmental hazards on human life. This work includes assisting with the drafting of laws, policy advocacy, environmental public interest litigation and networking with other environmental NGOS. FON has engaged in:

(1) Promoting over 40 important pieces of environmental legislation, including the Environmental Protection Law, Regulations on Open Government Information, the Air Pollution Prevention Law and the Soil Pollution Prevention Law.

(2) Launching a series of influential and strategic environmental public interest litigation cases. To date, FON has filed over 40 such lawsuits in various fields. Among them, 34 cases were accepted by the courts, including four water pollution cases, 12 atmospheric pollution cases, two climate change cases, six soil pollution cases, seven ecosystem destruction cases, one ocean conservation case and two administrative public interest litigation cases. In total 17 cases have been concluded so far.

(3) Establishing a support network for public interest litigation: more than 30 environmental protection organizations and more than 100 lawyers in the network have participated in environmental public interest litigation in different forms.

Based on the experience of litigating cases since $2011,{ }^{2}$ the FON legal team has recently devised a strategy to divide environmental law cases into six fields:

1 Friends of Nature, Blue Sky Lab <http://www.fon.org.cn/index.php?option=com_content\&v iew $=$ featured $\&$ Itemid $=247>$.

2 Friends of Nature commenced its first environmental public interest litigation in 2011, the chromium slag pollution case in Qujing. Summaries of the Friends of Nature cases are published in Chinese in regular Environmental Public Interest Litigation Bulletins; see Friends of Nature <www.fon.org.cn/index.php?option=com_k2\&view=item\&id=13730: 2019-7\&Itemid=178>. Some of these cases are also canvassed in Richard ZHANG Qing 
(1) Rule of Law issues, to protect the environmental rights of the public; (2) Public health issues, to control water, atmospheric and soil pollution; (3) Climate justice issues, which concern shifting energy consumption to a climate-friendly approach; (4) Ocean Conservation, aimed at reducing landbased marine pollution and to control coastal development and construction (5) Biological diversity conservation, to protect wildlife in biodiversity hotspots and other important habitats. (6) China's Belt and Road Initiatives, to promote responsible investment of transnational corporations. This strategy means that Friends of Nature will not only focus on individual legal cases, but also pay more attention to background systemic problems of particular industries and geographic areas.

In May 2019 the FON legal team noticed that a company named Bohu (a sewage treatment plant) in Jiangxi Province had been named in a government bulletin by the Ministry of Ecology and Environment for its alleged illegal discharge of pollutants. After detailed information retrieval and field research, FON came to the conclusion that the company's frequent excessive discharge of sewage is polluting the surrounding environment. In the context of present technology and equipment, most sewage treatment plants cannot meet the industry discharge national standards set by the central government. ${ }^{3}$ Considering the adverse effects of this pollution on the public interest, this case was considered an important one to serve as a warning to other sewage treatment plant companies and facilities. Accordingly, FON decided to file an environment public interest lawsuit against the Bohu company. FON claimed standing to sue under the 2014 Environment Protection Law.

By way of background, this water pollution case is similar to two other cases filed by FON. In 2018, FON separately sued two municipal solid waste incinerators ${ }^{4}$ because of their illegal pollution discharges. However, both

and Benoit MAYER 'Public Interest Environmental Litigation in China' Chinese Journal of Environmental Law 1 (2017) 202-228.

3 The discharge standard of pollutants for municipal wastewater treatment plants is issued by the Ministry of Ecology and Environment and the State General Administration of Quality Supervision, Inspection and Quarantine.

4 In January 2018, Yancheng Intermediate People's Court accepted the case of Friends of Nature v Jiangsu Daji Energy Co. Ltd. In April 2018, Friends of Nature sued Anqing Wanneng Energy Co. Ltd in the Anqing Intermediate People's Court in Anhui Province. These two cases are ongoing. 
defendants argued that they could not close their operations in order to upgrade their technology and equipment, because the local government would not allow it. It was therefore difficult to meet the emission standards and the companies maintained that as they must continue to operate, they had no choice but to keep polluting the air. In China, it is important to understand that some infrastructure enterprises such as municipal solid waste incinerators and sewage treatment plants are public-private partnership (PPP) projects. The two defendants and Bohu company are state-owned enterprises (soes) with PPP franchises in order to distribute the work. If they refuse to receive the garbage or sewage, the soEs argue that this will cause more social problems. But according to the Tort Law of the People's Republic of China 2010, ${ }^{5}$ such reasons cannot be used as an excuse either for the two municipal solid waste incinerators or the Bohu company to avoid their tortious liability.

In the Bohu case, there are four aspects to the litigation. FON has asked for cessation of the infringing acts, compensation for environmental damage (based on a judicial appraisal report provided by an expert appointed by the judge), an apology to the public for the pollution and to pay all costs incurred in the proceedings. However, the Nanchang Intermediate People's Court rejected the complaint for the reason that Friends of Nature's registered business does not include anything about 'water pollution'. According to the Interpretation of the Supreme People's Court on Several Issues concerning the Application of Law in the Conduct of Environmental Civil Public Interest Litigation, ${ }^{6}$ the court considered that since there is no description of water protection in the articles of association, FON failed to meet the requirements of the Environment Protection Law. The Jiangxi Provincial Higher People's Court accepted the petition for appeal on August 16, 2019. On August 28 2019, the Environment Division of the Jiangxi Provincial Higher People's Court made a final ruling: withdraw the ruling made by Nanchang Intermediate People's Court, and designate Nanchang Intermediate People's Court to exercise its jurisdiction to hear the case.

The Higher People's Court deemed that article 4 of the Interpretation is to ensure that social organizations have the capability to litigate. The FON's articles of association include that FON should 'comply with the Constitution,

5 Article 65 states 'Where any harm is caused by environmental pollution, the polluter shall assume the tort liability'.

6 Article 4: 'Where a social organization's tenets and main business scope specified in its articles of association are to maintain the public interest and it engages in public environmental protection activities, it may be determined as specially engaged in public environmental protection activities prescribed in Article $5^{8}$ of the Environmental Protection Law as amended in 2014'. 
laws, regulations and national policies, abide by social morality and to promote sustainable development by advocating ecological civilization and carrying out environmental research', which clearly includes the protection of the water environment. This provision of the articles of association, together with the experience since 2011 in conducting legal cases, is the basis on which the Friends of Nature should be considered as a qualified plaintiff, and why the Bohu case should be accepted by the courts.

\section{$3 \quad$ Standing under the Environment Protection Law}

Since the revised Environment Protection Law ${ }^{7}$ took effect in 2015, social organizations have the right to file environmental public interest litigation under article 58 . Based on both the law and judicial practice, there are four different types of organizations that can act as the plaintiff in environmental public interest civil litigation: (1) Procuratorial organs (knows as 'procutorates', which are government agencies); (2) Qualified environment protection organizations; (3) Government organs authorized by law (for example in the marine environment protection area); and (4) local governments (ecological damage compensation litigation). FON and many other environmental NGOs fall under the description of 'qualified environment protection organizations'. Although article 13 of the Interpretation (see above) stipulates that the litigation rights of social organizations have priority over procuratorates, there are still restrictions on the scope of environment public interest litigation cases that social organizations can initiate. On the one hand, it is difficult for social organizations to reach a good cooperative relationship with procuratorates or local governments. On the other hand, the courts are still very conservative and cautious about the attitude towards social organizations, despite the fact that courts at all levels now have specialist environment divisions and a substantial

7 Article 58: For activities that cause environmental pollution, ecological damage and public interest harm, social organizations that meet the following conditions may file litigation to the People's Courts:

(1) Have their registration at the civil affairs departments of People's Governments at or above municipal level with subdistricts in accordance with the law;

(2) Specialize in environmental protection public interest activities for five consecutive years or more, and have no law violation records.

Courts shall accept the litigation filed by social organizations that meet the above criteria. The social organizations that file the litigation shall not seek economic benefits from the litigation. 
number of judges have received specialist training in environmental law. The Bohu case experience is a typical illustration of these of difficulties.

Over the five years since standing has been expanded for public interest litigation, 298 cases filed by social organizations have been accepted nationwide and 119 of these cases have been concluded. ${ }^{8}$ The number of these cases is still small, compared with the 3964 environmental public interest administrative litigation cases filed by government procuratorial departments and accepted by the various courts around China; among these, 2796 cases have been concluded. These statistics indicate that difficulties still exist for social organizations to file environmental public interest lawsuits.

When the Environmental Protection Law came in effect, there was much discussion around the qualifications of potential plaintiffs, and the question of standing has often been the focus of the case itself. ${ }^{9}$ With the increase of environmental public interest cases, some judgments and relevant judicial interpretations have clarified what requirements should be met by social organizations in order to qualify as a plaintiff, as set out below.

In 2016, the Supreme People's Court's Guiding Case No. 75 for the Tengger Desert case $^{10}$ (brought by the China Biodiversity Conservation and Green Development Foundation), stated in relation to article 4 of the Interpretation:

(1) Although the articles of association do not specify that the tenets of the China Biodiversity Conservation and Green Development Foundation are to protect or maintain the environment public interest, the content of the work falls under the protection of environmental factors and ecosystems, and thus it should be confirmed to meet the requirement of Article 4 of the Interpretation, which reads: 'a social organization's tenets and main business scope specified in its articles of association are to maintain the public interest and that it engages in public environmental protection activities'.

(2) The 'environmental protection activities' as stipulated in article 4 of the Interpretation not only include the actions which can directly improve ecological conditions, but also include activities related to environmental

8 Data from news release conference of Adjudication Tribunal for Environment and Resources of the Supreme People's Court, July 30, 2019.

9 The evolution of standing to sue in environmental cases in China is traced in Tiantian Zhai and Yen-Chiang Chang, 'Standing of Environmental Public-Interest Litigants in China: Evolution, Obstacles and Solutions' (2018) 30(3) Journal of Environmental Law 369, esp at $373-375$.

10 Supreme People's Court No. 75 Guiding Case was released on December 28th of 2016: China Biodiversity Conservation and Green Development Foundation v Ningxia Tairui Pharmaceutical Company. 
protection that can improve the environmental governance system, improve environmental governance capacity, and promote the environmental protection perceptions of the whole society.

(3) If an environmental public interest lawsuit filed by a social organization has a corresponding relationship with the social organization's tenets and main business, or has a certain relationship with the environmental elements and ecosystems that the social organization protects, it shall be deemed to be in conformity with article 4 of the Interpretation.

The Supreme People's Court is thus of the view that the common interest held by the public of living in a healthy, comfortable and beautiful environment exist in various forms. Whether the tenets and main business include the protection or maintenance of the environmental public interest should be judged according to its practical work rather than simply based on the text of article 58 of the Environment Protection Law and article 4 of the Interpretation. Thus even if there is no description of environmental protection in the organization's articles of association, but its work focuses on the protection of various natural or artificially modified natural aspects of the environment that affect human survival and development (including the atmosphere, water, ocean, land, mineral deposits, forests, grasslands, wetlands, wildlife, cultural relics, nature reserves, scenic spots, cities and villages, and the protection of ecosystems), these can all be identified as tenets and its main business of protecting or maintaining the environmental public interest. Accordingly, as the Higher People's Court found (see above) under this an interpretation, Friends of Nature ought not to have any problem qualifying as the plaintiff in relation to the Bohu case or similar cases.

Although it is a typical water pollution case, the Bohu case nevertheless has particularities and difficulties. First of all, the limitation of action for environmental infringement cases is three years. Thus, a large amount of data must be collected and analyzed to confirm by how much the defendant has exceeded the sewage discharge standard in the past three years. Secondly, the external environment for sewage disposal in the Bohu case is the Ganjiang River, which forms a main branch of the Yangtze River in Jianxi Province. However, the defendant is by no means the only company that discharges pollutants to the Ganjiang River. Thus, after confirming the amount of sewage illegally discharged, the calculation of the impact and damage to the environment is another difficulty. 
Although there are many problems, the Bohu case is very significant in several aspects. From the perspective of the Bohu Company itself, the bringing of environmental public interest litigation against it can assist in requiring the defendant to upgrade its technology and equipment so as to meet the industry discharge standard. From the perspective of the entire industry, according to the 'polluter pays principle', the environmental damage compensation paid by the Bohu company can give other sewage treatment plants a warning that they must comply with environmental laws and regulations. The litigation can thus also act as a deterrent to others. In addition, as a downstream enterprise, if the sewage treatment plant pays more attention to whether the effluent water quality can meet the pollution discharge standards, it will encourage and promote more environment-friendly development and practices of upstream enterprises.

After the representations by Friends of Nature, the Jiangxi Provincial Higher People's Court finally approved its standing to sue in this water pollution case. There will no doubt be more difficulties in the trial of the Bohu case, but there will also likely be more ideas generated about how to address and solve the environmental problems of sewage treatment plants in China in general. 